\title{
Critical Review of Research Findings on Information Technology in Education
}

\author{
Lina MARKAUSKAITE \\ Institute of Mathematics and Informatics \\ Akademijos 4, LT-2021 Vilnius, Lithuania \\ e-mail:lmark@takas.lt
}

Received: March 2003

\begin{abstract}
This article analyses the field of research on information and communication technology (ICT) in education. It reviews the results of ICT researches carried out in the world. First, the article presents the retrospective of researches on ICT implementation into education. Summarizing them, it reviews main research findings in five areas of ICT implementation: 1) the impact of ICT use on students achievements and attitudes; 2) the impact of ICT use on teachers; 3) the effect of teachers' factors and instructional methods on ICT efficiency; 4) the influence of infrastructure and organizational factors on ICT efficiency; 5) the effect of specific software design features. Then, the paper reviews the main recent and future directions of researches on ICT in education, in the world. Finally, it shortly reviews the most important future directions of ICT research and development in Lithuania. The article concludes that in spite of numerous ICT studies worldwide the national research and experiments have to be carried out in order to implement ICT in an appropriate for Lithuania and efficient way.
\end{abstract}

Key words: information and communication technology (ICT), implementation of ICT into education, research of ICT implementation, efficiency of ICT in education, use of computers in education.

\section{Introduction}

The implementation of information technology into education is being researched for more than twenty years. Scientists from various countries carry out thousands of research every year (Research Report, 2000). Different aspects of computers integration into education are investigated: their pervasion, methods and efficiency of use. The evolution of researches reflects the development of technologies, the changes in education, and the tendencies of computers' use in education. Earlier and present researches differ not only in the obtained results, but also in their goals and methodology.

The goal of this article is to analyse and summarize global experience of research on ICT implementation in education. It aims to demonstrate a variety of previous and present researches and their findings. However, enormous number of researches has been carried out in this field all over the world. For example, the report of "Software and Information Industry Association" states that works summarized in their analysis were selected from more than 3500 researches, carried out in 1990-1999 (Research Report, 
2000). Therefore, it is almost impossible to review all studies on ICT use in education. For this reason, the methodologies of secondary and third-level analysis and synthesis are applied in this investigation. The object of this study is research reports of world-wide international studies, research reviews and meta-analyses.

Initially, this article gives a short retrospective of researches in the field of new technologies in education. Then, it separates out the main types of investigations on ICT implementation into education. Sequentially, it synthesizes the results and presents a review of the main and most typical findings in each field of ICT research. Finally, it discusses the most recent issues of ICT research in the world and in Lithuania and draws the conclusions.

\section{Retrospective of ICT Development and Research}

The USA was the first country, which started implementation of computers into education. It was concerned about the inefficiency of educational system of the USA and the danger that the country can get behind the Soviet Union. To prevent that, in the 70s, almost all USA universities and colleges were provided with computers (Anderson, 1996). In the beginning of the 80s, ICT were introduced into secondary schools too. Several years later, West European and industrialized countries of the Far East also started the introduction of ICT into general education (Collis and Lai, 1996). World-wide international studies show (Pelgrum and Plomp, 1991; Pelgrum, 1993; Pelgrum and Anderson, 2001) that in the middle of the 90s computers were widely available in the majority of upper and lower secondary schools of many countries, and they were just introduced into primary education. The level of ICT availability at schools was very different even in industrialized countries. For example, at the end of the 80 s, all primary, lower and upper secondary schools of the USA were equipped with computers, meanwhile the ICT was available in upper secondary schools only, in many countries of West Europe and the Far East. The international surveys conducted in 1992 and 1998 years show (Pelgrum, 1993; Pelgrum and Anderson, 2001) that in the beginning of the 90s, lower secondary schools of these countries were provided with ICT tools too; and in the end of this decade, computer penetration at primary schools reached the level of USA, as well.

The existence of computers at schools per se does not mean that the ICT were integrated into the process of education effectively. Above referred international surveys prove this assertion. The ICT implementation into education was and still is not sufficiently efficient because of various technical, organizational and methodical constrains (Pelgrum, 1993; Pelgrum and Anderson, 2001).

In the middle of the 70s, scientists, computer specialists and teachers started to worry about the inefficiency of computers for teaching and learning. In the USA, the National Fund of Science initiated and financed a big number of experiments and surveys on ICT use in education (Anderson, 1996; Collis, 1996). Then, in the early years, it was believed that new technologies would improve teaching and learning and would make better students' knowledge. Therefore, ICT implementation into education was associated with 
the ideas of programmed instruction (see Eraut, 1996) and with the potential of ICT to improve traditional teaching methods.

The first researches have analysed the influence of educational software (drill and practice, tests, computerized textbooks, etc.) on students' knowledge of different subjects. Though results showed the benefit of computer use, the positive effect was quite small (Walker, 1996).

When personal computers become available, the ICT was introduced into secondary schools not only as a mean for teaching and learning, but also as an object of learning. The majority of countries introduced separate informatics curricula into secondary education (Newby et al., 1996). At the same time, many experiments were carried out. It was looked for new more powerful ways of ICT use. Not only the efficiency of tools but also different other aspects of ICT integration into teaching and learning were investigated. The metaanalyses of the first research results do not separate various forms of computer-based education and analyse their aggregate efficiency. Therefore, the first reviews do not go deeper into analysis of the goals of ICT use; and sometimes they even not isolate the ICT is an object of learning and ICT as a tool for learning. The summation of reviews and meta-analyses of that time maintains that information technology can have positive influence on students' knowledge. Such result was obtained in the majority, but not in all, researches (Edwards et al., cit. Sinko and Lehtinen, 1999). The results of meta-analyses were positive too, however the size of estimated influence was low (Kulik et al., cit. Culp et al., 1999).

Later, it was noted that the efficiency of computers must not be isolated from other factors of educational process. The usefulness of new technologies can depend on different factors - such as, students characteristics, teaching and learning methods, opportunities to access ICT and etc. (Culp et al., 1999; Sinko and Lehtinen, 1999). Therefore, the later meta-analyses measure not only the absolute influence of computers, but also consider the links between ICT and various factors of learning - students grade, sex, type of applied software, etc.

In the last decade, the development of information technology was interflowed with the educational change. As a consequence, goals and ways of computer integration into education changed as never noticeably. The progress of researches of ICT implementation into education mirrors these transformations, too. Goals of studies and analysed aspects of ICT integration have changed substantially. New special methods that investigate various factors of ICT use are applied now. The efficiency of new technology is assessed not only according to the final students knowledge, but also according to students' progress, impact on their general abilities. Nowadays, the ICT is often investigated as only one of many factors that could have some influence on success of education.

Summarizing all findings, the most important research can be classified into several categories: 1) impact of ICT use on students' achievements and attitudes; 2) impact of ICT use on teachers; 3 ) influence of teachers' factors and instructional decisions on ICT efficiency; 4) infrastructure characteristics and organizational factors that promote useful use of ICT; 5) effect of specific software design features on the efficiency of learning. Lets review the main findings in each of these groups separately. 


\section{Impact of ICT Use on Students' Achievements and Attitudes}

On the ground of findings of meta-analyses and research reviews, we can state that ICT has positive impact on students' achievements of different subjects - i.e., computers make learning easier and students learn faster (Christman et al., 1997; Fidzgerald and Koury, 1996; Lehtinen et al., 1998; Liao, 1998; McCoy, 1996; Reed, 1996; Research Report, 2000; Sinko and Lehtinen, 1999). This finding is not absolute: some assessments, carried out in different years, did not show any positive impact of computers, and sometimes they produced even negative impact (Sinko and Lehtinen, 1999).

Many researches demonstrate that ICT has positive impact on students of different age and different abilities and almost in all subjects. However, the size of effect depends on subject, student grade, applied software and other factors (Cotton, 1992; Research Report, 2000).

Already the first meta-analyses and research reviews on efficiency of computer in teaching different basic skills (e.g., to read and to calculate) seek to determine, whether different methods of computer use are equally efficient (Edwards et al., cit. Sinko and Lehtinen, 1999; Stennets, cit. Sinko and Lehtinen, 1999). It was estimated that learning only with educational software is much less effective than combination of computerbased learning with other non-computer based educational methods. Later assessments confirmed this finding, too (Research Report, 2000).

In different scientific works, the reliance of the efficiency of computers on other factors is assessed. The results of many experiments show that drill and practice and teaching programs are more effective for younger students, for children from families of lower socio-economic level and for less gifted pupils (Cotton, 1992; Sinko and Lehtinen, 1999). Findings reveal that the relationship between the different factors and ICT efficiency is not static and it could change over the time (Fletcher-Flinn and Gravatt, 1995).

The efficiency of ICT depends on student's sex and other physical features. Many researches show that information technology has some greater impact on boys' achievements and attitudes than on girls (Cotton, 1992; Thompson et al., 1996). However, the difference typically is very small. Some researches even show that new technology has greater positive impact on girls. For example, Lehtinen's et al. (1998) review presents results of several researches, which demonstrate that some forms of computer use are more effective for girls than for boys. It is clearly noticed that various methods of computerbased learning are especially efficient for students with disabilities (Ayersman, 1996).

Some scientific works have analysed the impact of features of experiments on their results (Christmann et al., 1997; Khaili and Shashaani, 1994; Liao, 1998). The metaanalyses of Christmann et al. (1997) that summarize the results of studies on programmed instruction, carried out in 1984-1995 years, present very interesting findings. The results have shown that the effect of these educational programs decreases over the time. In other works, another interesting impact of time factor was observed. Researches founded, that the estimated positive effect of ICT is smaller in long experiments than in short ones, but very short experiments do not show considerable efficiency too (Khaili and Shashaani, 1994; Liao, 1998). Meta-analyses reveal that the impact of ICT correlates 
with the size of experimental group. Experiments with small group of students are often very successful, whereas the effect usually smaller when the experimental group is large (Khaili and Shashaani, 1994; Liao, 1998).

Comparing the results of previous and present researches, one can notice their substantial differences. Recent researches do not find difference of ICT impact on students of different grades, meanwhile previous researches used to find it. Early researches show that drill and practice, and programmed instruction are the most effective ways of computer use into education. For the present, researches show the greatest effectiveness of computer-based learning environments and other tools suitable for constructivistic approach. Sinko and Lehtinen (1999) suggest that these changes in findings can be associated with both development of new educational environments and advance of research techniques (i.e., the invention of new, more reliable methods for assessing learning outcomes and students thinking abilities).

Fletcher-Flinn and Gravatt (1995) have investigated the impact of ICT in teaching of different subjects. They have determined that the effect on achievements of different subjects is not the same: the greatest benefit of computers is noticed in teaching mathematics. Robyler (cit. Thompson et al., 1996) in his meta-analyses also found out that computers are more efficient in teaching mathematics than reading and writing skills. However, when the ICT is used for the development of cognitive skills, the technology is equally efficient in learning of both subjects. The scientist also determined that ICT is very useful for teaching and learning of natural sciences.

Analyses of other researches on ICT use for teaching various subjects demonstrate different effectiveness of different computer-based education forms (Cotton, 1992; Research Report, 2000). For example, in learning languages, ICT is effective for developing phonetics and reading skills and for memorizing new words. During lessons of natural sciences, imitation programs and computer-based laboratories are effective. In geography, tools for telecommunication and cooperative learning can be used effectively. Wilde rage of computer-based forms can be effectively applied into lessons of social subjects (Research Report, 2000).

In many researches, it is detected that teaching of programming languages develops general student's abilities of task solving and thinking (Liao et al., cit. McCoy, 1996). However, in the past, programming is not taught in the comprehensive schools of most countries, so there are very few recent researches in this field. Only some scientific works that investigate the integration of computers into teaching of mathematics and the effectiveness of learning environments (e.g., Logo) analyse the effectiveness of programming, too. Researches reveal that Logo language is the most suitable for teaching mathematics. ${ }^{1}$ Logo is much more effective than Basic and slightly more useful than Pascal language (McCoy, 1996). Logo is effective for learning mathematics for students of all grades, especially younger ones.

Many researches detect positive impact of ICT on students' attitudes. They observe improved students' opinion about school, learning and teaching process, a subject, computers and their use for education (Cotton, 1992). The findings also show higher children

\footnotetext{
${ }^{1}$ This finding concerns not all LOGO learning environment, but only LOGO programming language.
} 
motivation to learn about computer use and to learn other subjects. In the report of Software and Information Industry Association of 2000 year (Research Report, 2000), where the findings of 311 researches of ICT implementation into education are generalized, it is noted that the greatest positive impact of information technology on students' motivation was determined in learning mother tongue, mathematics and natural sciences. The application of telecommunications and video technology especially increases students' motivation. Researches also detect extremely positive impact of ICT on the attitudes of students with disabilities (Research Report, 2000).

The findings of recent years show that the efficiency of ICT depends not only on software features, but also on compliance of new technological tools with educational targets, the methods of the integration, and student's features (Research Report, 2000).

\section{Impact of ICT Use on Teachers}

Cradler and Bridgforth (1996) summarize more than 100 researches and state that the integration of ICT helps teachers to shift from traditional teacher-centred to student-centred educational approach. Findings show that information technology has impact on teachers and the way the teachers work. In general, researches observe the most positive results in the following domains: 1) teachers upgrade teaching curricula and their teaching and learning methods; 2) give more consideration to individual teaching; 3 ) spend more time on consulting of students; 4) get more interested in education; 5) experiment more with new technology; 6) work in a more productive way, more plan and cooperate with colleagues; 7) more willingly take part in other projects of educational change at school and in region; 8) associate more with parents and colleagues (Crandler and Bridgforth, 1996; Martin et al., 2002).

\section{Characteristics of Infrastructure and Organizational Factors}

Researches reveal that infrastructure characteristics and organizational factors influence efficiency of ICT integration into education. Researches that analyse the influence of these factors at various levels of education system (i.e., classroom, school, region and country) are summarized in a number of reviews (Cradler, 1994; 1996; Cradler and Bridgforth, 1996; Dusick, 1998; Grunberg and Summers, 1992; Michael, 1998; Research Report, 2000). For example, Dusick (1998) and Michael (1998) deeply investigate the impact of school level factors; Cradler $(1994,1996)$ analyses the factors of a region and a country. Generalizing their findings, we can state that ICT can be efficiently integrated into educational process only if infrastructure and organizational factors, at the level of school and country, satisfy several main conditions. For instance, goals of ICT integration have to be coherent with general goals and standards of education. Teachers have to know how ICT should be integrated into educational process. The system for teachers ICT skills development and support should be established. Schools should have proper conditions to use fitting technology and software. Special time should be allocated for 
teachers ICT development and for their preparation to integrate computers into subject curricula. The system of technical support and maintenance should be established.

Presently specialists of education and scientists of many countries are getting interested into impact of education management on the efficiency of ICT implementation (e.g., Law et al., 1999). They consider that proper management is an important factor for the success. This factor mainly decides, whether or not ICT implementation into teaching and learning process helps to achieve broader goals of educational reform.

\section{The Influence of Teachers' Factors and Instructional Decisions on ICT Efficiency}

Many researches find out that a teacher is the prime factor that determines the usefulness of ICT in teaching and learning (Dusick, 1998; Ryan, cit. Sinko and Lehtinen, 1999; Research Report, 2000). The report of Software and Information Industry Association notes that teacher's role is critical in creating new efficient information technology-based learning environment (Research Report, 2000). The main characteristics of such environment are carefully planned process of education and permanent interaction between a teacher and a student. This document states that teacher's readiness and knowledge how to integrate ICT can be even more important factors than the frequency of computers use.

The meta-analysis of Ryan (cit. Sinko and Lehtinen, 1999) shows positive impact of proper teacher's preparation on the efficiency of ICT use, too. He estimated that in experimental classes, where teachers had learned about implementation of computers into education less than 5 hours, the effect of ICT use was much smaller than in the classes, where teachers had learned to do that more than 10 hours. In addition, this work states that students achieved better results in those classes, where teachers have used educational tools developed by themselves, compare to those classes, where teachers have used commercial products.

Researches show critical teacher's role in the learning process, where constructivistic methods and suitable for this educational approach ICT tools are used (Cotton, 1992; McCoy, 1996; Reed, 1996; Research Report, 2000). For example, early researches display positive impact of communications tools on student's writing skills (Reed, 1996), meanwhile later works reveal that individual students correspondence by e-mail and communication via the Internet, which is not guided by the teacher do not yield any positive impact on students' writing (Research Report, 2000). Experiments on integrating Logo programming language into teaching of mathematics also confirm the importance of teacher's role. If students apply this programming language or other micro-worlds without proper teachers' supervision, they learn to solve tasks only in an experimental way, and do not get understanding of the underlying concept of the solution (McCoy, 1996).

As it was mentioned before, the efficiency of ICT depends on the compliance of methods of ICT integration with learning goals and with student's features. Fundamental role of adequacy of educational methods is confirmed by many experiments (Cotton, 1992; Lehtinen et al., 1998; Liao, 1998; Reed, 1996; Research Report, 2000). For example, 
researches reveal that learning with computers in small groups is more effective than individual learning (Lehtinen et al., 1998). Group-work has positive impact on both students' achievements and their attitudes. This method creates especially positive influence outcome on girls and less skilled students.

In order to develop students' cognition and problem solving skills during lessons of mathematics, it is important to integrate information technology in proper way, as well (Research Report, 2000). Computers are helpful only then, when they are used for solving tasks and their use is combined with practice, experiments and other methods of constructivistic education.

Researches on ICT use for teaching languages also confirm the crucial role of appropriate education methods. Word processors or other content free tools are efficient for developing writing skills (Cotton, 1992; Research Report, 2000). Studies show that students write longer texts, use broader dictionary, bigger variety of grammatical structures, and etc. However, this effect is attained only in that case, when the writing software is used in a methodical way and the emphasis is given on the process of writing and not the final text.

\section{The Effect of Specific Software Design Features}

A large number of scientific studies investigate the influence of various features of ICT tools on the efficiency of learning and teaching (Research Report, 2000). This chapter reviews some most common and important findings.

Computer programs that use bigger variety of different forms to present the information (e.g., text, graphics and sound) are more effective (Research Report, 2000).

Drill and practice programs that provide clues and the right answer are more effective than those programs, which make students to find out the right answer themselves. Moreover, programs that explain, why the answer is wrong, are more effective than those programs, which only show what is wrong (Research Report, 2000).

Berson (1996) analyses the efficiency of simulation programs for teaching social science. The scientist notes that when the program does not provide the possibility for students to get necessary information related to the task or get other help at the right moment, the efficiency of simulation software is very low.

Review of Reed (1996) shows relationship of efficiency of specific software design features and student's features. Content free word processors suit better for elder students and for those who already have rather good writing skills. Meanwhile programs that help to structure a text and control the process of writing suit better for younger students and for those whose writing skills are weak.

\section{Tendencies of Researches of ICT Implementation into Education in the World}

In the world, presently information technology is applied in teaching and learning of various subjects, it is widely integrated into whole process of learning and into entire 
system of education. Holistic learning approaches, modern methods of constructivistic learning and new understanding of school community as well as new communication technologies change the role of ICT in education too. Now ICT is being incorporated into all aspect of life at school. These tendencies can be noticed in new researches and plans of ICT implementation (Guzdial and Weingarten, 1996; Research Report, 2000; Sinko and Lehtinen, 1999). Many researches of this field that recently have been carried out or are under the way are designated for the assessment of the efficiency of new technology, the analysis of educational methods and various other aspects of ICT implementation. Culp $e t$ al. (1999) generalize new tendencies of ICT implementation into education and discuss most recent directions of the researches in this field. They separate 14 most promising thematic fields for the future experiments and studies (Fig. 1). Summarizing all, we can note that various dimensions of the development of information abilities are investigated particularly broadly and deeply in the recent studies worldwide (Markauskaitè, 1999a).

Applied methods for researches of ICT implementation also reflect the recent tendencies in school change and in education researches (Culp et al., 1999; Markauskaité, 1999b, 2002). The number of empiric investigations decreases both, in the field of ICT implementation as well as in the education studies in general. Naturalistic approach starts

\begin{tabular}{|c|c|c|}
\hline $\begin{array}{l}\text { 1. Making real-world } \\
\text { connec tions }\end{array}$ & $\begin{array}{l}\text { 2. Fng aging in complex } \\
\text { analysis }\end{array}$ & $\begin{array}{l}\text { 3. Medi a and information } \\
\text { literacies }\end{array}$ \\
\hline $\begin{array}{l}\text { 4. Inme, school and } \\
\text { commenity conneetions }\end{array}$ & $\begin{array}{l}\text { 5. Te acher learning and } \\
\text { professional eommunity }\end{array}$ & $\begin{array}{l}\text { 6. Reorganizing the } \\
\text { edecation workplace }\end{array}$ \\
\hline $\begin{array}{l}\text { 7. Equity and access, } \\
\text { gender and s pecial } \\
\text { edecation }\end{array}$ & $\begin{array}{l}\text { DIRECTIONS FOR RED } \\
\text { WORK ON ICT IN } \\
\text { EDECATION }\end{array}$ & $\begin{array}{l}\text { 8. RA D on emerging } \\
\text { technologies asd } \\
\text { challenging, difficult } \\
\text { content }\end{array}$ \\
\hline $\begin{array}{l}\text { 9. Inter natienal stusies of } \\
\text { technology in education; } \\
\text { global context of teaching } \\
\text { and learaing with ICT }\end{array}$ & $\begin{array}{l}\text { 10. Using technology to } \\
\text { support lifelong lear ning }\end{array}$ & 11. Sexpercomputing \\
\hline 12. Assessment & 13. Telementaring & $\begin{array}{l}\text { 14. Computer-assisted } \\
\text { instruction }\end{array}$ \\
\hline
\end{tabular}

Fig. 1. Promising directions for future research and development work (adapted from (Culp et al., 1999)). 
to dominate in all fields of educational researches, including new technologies. More and more often different qualitative aspects of ICT implementation are investigated. ICT is usually analysed as one of many important elements of the whole complex educational process.

\section{Future Directions of ICT Researches into Education in Lithuania}

The world context of ICT research is not very favourable for Lithuania. Wide use of ICT for teaching and learning of informatics have been dominating for almost twenty years, in Lithuania (Ališauskas, 1991, 1993, 1994, 1995). Meanwhile, ICT integration in informatics has been little analysed in the world, as this way of computer use was not very common in other countries (Markauskaite, 2000). Thus, there is a lack of new investigations and reliable results in this research field. One common tendency can be observed, in Lithuania and in all countries where the tradition of teaching fundamental informatics knowledge dominates. The informatics curriculum is gradually shifting now from pure academic content to teaching of ICT skills, wider ICT integration with other subjects and the development of information abilities (Bendrojo ..., 1997; 1999; Dagiené, 1998; Lietuvos ..., 1997).

The shift from learning about ICT during the lessons of informatics to full integration of new technologies into overall process of education will inevitably rise new challenges at all levels of education system. It is evident that the legacy of fundamental informatics, in Lithuania, will create distinctive problems and specific opportunities, which are not common in other countries. For example, Lithuania has distinctive, focused only on one subject, ICT integration experience and disintegrated ICT curricula. The system of teachers' pre-service and in-service development and the ICT infrastructure at schools are also accommodated with this approach (Markauskaite and Dagiené, 2001). Therefore, researches of all specific aspects of ICT integration are essential, in Lithuania.

In addition, development of information abilities and other modern trends of education now only emerge. The in-depth analysis of information skills shows (see Markauskaite, 1999a) that information abilities involve not only practical skills, but also conceptual knowledge about ICT, information and informatics. Therefore, we can state that knowledge of informatics potentially could become an important part of information skills and overall comprehensive school curricula. ${ }^{2}$ These facts show the worldwide importance of researches of informatics subject in Lithuania.

Other essential for Lithuania aspects of implementation of new technologies into education are little investigated too. For example, it would be important to conduct different experiments and researches related to the most promising computer-based forms of education. Namely, such areas of research could be the following: the development of information abilities, methods and means for modelling, learning environments, use of telecommunications in teaching and learning, etc. These forms are not very common now, although they could be widely used for compulsory education, in the future. More

\footnotetext{
${ }^{2}$ However, the content of informatics should be changed substantially.
} 
attention should be given to the researches on using ICT in lower grades of secondary school, since computers have been introduced into compulsory education in lower secondary education just recently, in Lithuania (Dagienè, 1998). Considering low penetration of computers in Lithuanian schools, it would be relevant to investigate qualitative aspects of such methods of ICT use that can be effective in cases of scare technology resources (Kriščiūnienè, 1998).

From science and practice perspective, it would be useful to analyse the process of ICT implementation into school as an institution, in Lithuania (Markauskaite, 1999b). For instance, the effectiveness of the main organizational and management factors - such as, coordination of implementation, allocation of resources, development of teachers' qualification, etc. - has to be investigated.

Almost all questions, associated with the efficiency of the development and adaptation of educational software or other programs used for educational purposes are also still unexplored.

All that demonstrates that various national researches of ICT implementation into education are necessary for the cost-effective, meaningful, and successful implementation of national strategies (Informacijos ..., 2000; Mokyklu ..., 2002a) and programs (Informacijos ..., 2002; Mokyklų ..., 2002b) for ICT implementation into Lithuanian secondary schools.

\section{Conclusions}

In the world, ICT implementation into education is widely investigated. Researches have different goals and apply different research methods. The review of the ICT research results shows that the following aspects of ICT implementation into the process of education have been analysed most frequently:

1) the impact of ICT use on students achievements and attitudes;

2) the impact of ICT use on teachers;

3) the effect of teachers' factors and instructional decisions on ICT efficiency;

4) the infrastructure characteristics and organizational factors;

5) the effect of specific software design features.

Emerging directions of ICT implementation are consistent with the targets of overall education reform. These directions provide the guidelines for future research areas of ICT implementation into education, too.

It is especially important to carry out the national researches of ICT implementation into education, because many aspects of implementation of new technologies that are specific and relevant for Lithuania are not investigated elsewhere in the world.

\section{References}

Ayersman, D.J. (1996). Reviewing the hypermedia-based learning research. Journal of Research on Computing in Education, 28 (4), 500-525. 
Ališauskas, R. (1991). Mokyklinė informatika ir kompiuterininku mados (in Lithuanian, Informatics in secondary education and fashions in computing). In Kompiuterininku dienos'91, Birštonas, pp. 7-14.

Ališauskas, R. (1993). Kompiuteriniai žaidimai su švietimu (in Lithuanian, Computer games with education). In Kompiuterininkuc dienos'93, Vilnius, pp. 15-19.

Ališauskas, R. (1994). Informatika Lietuvos mokyklose: nuo ištaku ateities link (in Lithuanian, Informatics in Lithuanian schools: from the beginning toward the future). Informacijos mokslai, 2, 47-59.

Ališauskas, R. (1995). Ką mes darème, darome ir darysime su jūsų vaikais (in Lithuanian, What we did, do and will do with your children). In Kompiuterininkuc dienos'95, Vilnius, Žara, pp. 119-129.

Anderson, R.E. (1996). The United States context of computers in education. In T. Plomp, R.E. Anderson and G. Kontogiannopoulou-Polydorides (Eds.), Cross National Polices and Practices on Computers in Education. Kluwer Academic Publishers, Dordrecht, pp. 445-468.

Bendrojo išsilavinimo standartai. I-X klasès (1997). Projektas. I ir II dalys (in Lithuanian, Educational standards for comprehensive school. Project. Vol. 1 and 2). Leidybos centras, Vilnius.

Bendrojo lavinimo mokyklos bendrosios programos ir išsilavinimo standartai XI-XII klasei (1999). Projektas. IIV dalys (in Lithuanian, General curricula and educational standards for 11 and 12 grades. Project). Leidybos centras, Vilnius.

Berson, M.J. (1996). Effectiveness of computer technology in social studies: a review of the literature. Journal of Research on Computing in Education, 28 (4), 486-499.

Christmann, E., J. Badgett and R. Lucking (1997). Progressive comparison of computer-assisted instruction on the academic achievement of secondary students. Journal of Research on Computing in Education, 29 (4), 325-337.

Collis, B. (1996). Computers in education. In T. Plomp and A.D. Ely (Eds.), International Encyclopedia of Educational Technology, 2nd ed. Pergamon, Great Britain, pp. 402-408.

Collis, B., and K.-W. Lai (1996). Information technology and children from a classroom perspective. In B. Collis, G.A. Knezek, K.-W. Lai, K.T. Myisashita, W.J. Pelgrum, T. Plomp and T. Sakamoto, Children and Computers in School. Mahwah, New Jersey, LEA, pp. 43-67.

Cotton, K. (1992). Computer-Assisted Instruction. School Improvement Research Series. 1991-1992. Close-Up \#10. USA, Northwest Regional Educational Laboratory. http://www.nwrel.org/ scip/sirs/index.html

Cradler, J., and E. Bridgforth (1996). Recent Research on Effect of Technology on Teaching and Learning. Policy Brief. San Francisco, CA, WestEd Regional Educational Laboratory. http://www. fwl .org/ techpolicy/research.html

Cradler, J. (1994). Summary of Current Research and Evaluation Findings on Technology in Education. San Francisco, CA, Far West Laboratory. http://www.fwl.org/techpolicy/ refind.html

Cradler, J. (1996). Implementing Technology in Education: Recent Findings from Research and Evaluation Studies. Policy Brief. San Francisco, CA, Far West Laboratory for the California Department of Education. http: //www. fwl.org/techpolicy/recapproach.html

Culp, K.M., J. Hawkins and M. Honey (1999). Review Paper on Educational Technology Research and Development, January. Center for Children and Technology, USA.

Dagiene, V. (1998). Privalomas informatikos kursas bendrojo lavinimo mokyklose (in Lithuanian, Compulsory informatics curricula in comprehensive schools). Informatikos mokslai, 8, 20-36.

Dusick, D.M. (1998). What social cognitive factors influence faculty members' use of computers for teaching? A literature review. Journal of Research on Computing in Education, 31 (2), 123-137.

Eraut, M. (1996). Programmed learning. In T. Plomp and A.D. Ely (Eds.), International Encyclopedia of Educational Technology, 2nd ed. Pergamon, Great Britain, pp. 394-402.

Fidzgerald, G.E., and K.A. Koury (1996). Empirical advantages in technology-assisted instruction for students with mild and moderate disabilities. Journal of Research on Computing in Education, 28 (4), 526-553.

Fletcher-Flinn, C.M., and B. Gravatt (1995). The efficancy of computer-assisted instruction (CAI): a metaanalysis. Journal of Educational Computing Research, 12 (3), 219-241.

Grunberg, J., and M. Summers (1992). Computer innovation in school: a review of selected research literature. Journal of Information Technology for Teacher Education, 1 (2), 255-276. http://rice.edn.deakin.edu.au/archives/JITTE/j129.htm

Guzdial, M., and F.W. Weingarten (Eds.) (1996). Setting a Computer Science Research Agenda for Educational Technology. Computing Research Association, USA. 
Informacijos ir komunikacijos technologijos diegimo Lietuvos švietime strategija (in Lithuanian, The strategy for the implementation of information and communication technologies into Lithuanian education) (2000) In Informacijos technologija mokykloje, Vilnius, Lietuvos Respublikos švietimo ir mokslo ministerija, Švietimo informacinių technologiju centras, pp. 153-197.

Informacijos ir komunikacijos technologijos diegimo švietimo sistemoje programa (in Lithuanian, The program for the implementation of information and communication technologies into education) (2002). In Informacinès technologijos mokykloje, Vilnius, Švietimo informaciniu technologijų centras, pp. 198-206.

Khaili, A., and L. Shashaani (1994). The effectiveness of computer applications: a meta-analysis. Journal of Research on Computing in Education, 27 (1), 48-61.

Kriščiūnienè, N. (Sud.) (1998). Vieno kompiuterio panaudojimas mokykloje (in Lithuanian, The use of one computer in a school). Eugrimas, Vilnius.

Law, N., H.K. Yuen, W.W. Ki, S.C. Li and Y. Lee (1999). Second International Information Technology in Education Study. Hong Kong SAR Report. CITE, HKU, Hong Kong.

Lehtinen, E., K. Hakkarainen, L. Lipponen, M. Rahikainen and H. Muukkonen (1998). Computer Supported Collaborative Learning: A Review. CL-Net. A Report for European Commission.

http://suvi.kas.utu.fi/papers/clnet/clnetreport.html

Liao, Y.-K.C. (1998). Effects of hypermedia versus traditional instruction on students' achievement: a metaanalysis. Journal of Research on Computing in Education, 30 (4), 341-359.

Lietuvos bendrojo lavinimo mokyklos bendrosios programos. I-X klases (in Lithuanian, General curricula for comprehensive school. 1-10 grades) (1997). Leidybos centras, Vilnius.

Markauskaitè, L. (1999a). Informaciniai gebejjimai humanitarinių ir tiksliujų mokslų sanglaudoje (in Lithuanian, Information skills as a liberal art and exact science). Informacijos mokslai, 10, 38-51.

Markauskaitè, L. (1999b). Informacijos technologijos diegimo ir mokyklos tobulinimo vertinimas (in Lithuanian, Evaluation of information technology implementation and assessment of school improvement). In Mokyklos tobulinimas informacijos amžiuje, Vol. 2. Žara, Vilnius, pp. 174-187.

Markauskaitè, L. (2000). Kompiuteriniu mokymo formu bendrojo lavinimo mokyklose analizè (in Lithuanian, Analysis of computer-based forms of learning in comprehensive schools). Doctoral dissertation. Institute of Mathematics and Informatics, Vytautas Magnus University, Lithuania.

Markauskaité, L. (2002). Information technology implementation: analysis of theoretical methods and frameworks. Informatics in Education, 1 (1), 111-128.

Markauskaitè, L., and V. Dagienè (2001). Informacijos ir komunikacijos technologijos diegimo Lietuvos švietime strategijos teorinis pagrindimas (in Lithuanian, Theoretical base of the strategy for implementation of information and communication technology into Lithuanian education). Socialiniai mokslai, 1 (27), 29-40.

Martin, W., A. Gersick, H. Nudell and K.M. Culp (2002). An Evaluation of Intel Teach to the Future. Year Two Final Report. September 2002. Center for Children and Technology, New York. http: / / www.edc.org/CCT

McCoy, L.P. (1996). Computer-based mathematics learning. Journal of Research on Computing in Education 28 (4), 438-460.

Michael, S.O. (1998). Best practices in information technology (IT) management: insights from K-12 schools' technology audits. International Journal of Educational Management, 12 (6), 277-288.

Mokyklų aprūpinimo mokomosiomis kompiuterinėmis priemonėmis strategija (in Lithuanian, The strategy for the provision of schools with educational software) (2002a). In Informacinès technologijos mokykloje, Švietimo informacinių technologijuc centras, Vilnius, pp. 207-226.

Mokyklų aprūpinimo programa, skirta Lietuvos tūkstantmečiui (in Lithuanian, The program for the provision of schools, dedicated to the millennium of Lithuania) (2002b). In Informacinès technologijos mokykloje, Švietimo informacinių technologiju centras, Vilnius, pp. 231-237.

Newby, T.J., D.A. Stepich, J.D. Lehman and J.D. Russell (1996). Designing Instruction, Integrating Computers, and Using Media. Englewood Cliffs, New Jersey, and Columbus, Ohio, Merrill, Prentice Hall Inc.

Pelgrum, W.J. (1993). Access to hardware and software by schools and students. In W.J. Pelgrum, I.A.M. Janssen Reinen and T. Plomp (Eds.), Schools, Teachers, Students and Computers: a Cross-National Perspective. IEA-Comped Study Stage 2. IEA, The Netherlands, pp. 7-26.

Pelgrum, W.J., and R.E. Anderson (Eds.) (2001). ICT and the Emerging Paradigm for Life Long Learning: a Worldwide Educational Assessment of Infrastructure, Goals and Practices. IEA, Amsterdam. 
Pelgrum, W.J., and T. Plomp (1991). The Use of Computers in Education Worldwide: Results from the IEA "Computers in Education" Survey in 19 Education Systems. Pergamon Press, Oxford, New York, Seoul, and Tokyo.

Reed, W.M. (1996). Accessing the importance of computer-based writing instruction. Journal of Research on Computing in Education, 28 (4), 418-437.

Research Report on Effectiveness of Technology in Schools: Executive Summary (2000). Software and Information Industry Association, USA. http: //www. siia.net.

Sinko, M., and A. Lehtinen (1999). The Challenges of ICT in Finish Education. Atena, Finland.

Thompson, A.D., M.R. Simonson and C.P. Hargrave (1996). Educational Technology: a Review of the Research, 2nd ed. Association for Educational Communications and Technology, Washington.

Walker, D.F. (1996). New information technology in the curriculum. In T. Plomp, and A.D. Ely (Eds.), International Encyclopedia of Educational Technology, 2nd ed. Pergamon, Great Britain, pp. 539-545.

L. Markauskaite is a research fellow of the Institute of Mathematics and Informatics, in Lithuania. She received the PhD in informatics, in 2000. Her major research interests are qualitative and quantitative research and data analysis and all aspects of implementation of information technologies into education. The interests also include the issues of telecommunications market liberalisation, provision of universal telecommunications services, and the issues of information society development.

\section{Informacijos technologijos diegimo švietime tyrimu rezultatu kritinė apžvalga}

\section{Lina MARKAUSKAITE்}

Šiame straipsnyje nagrinejjami informacijos ir komunikacijos technologijos (IKT) diegimo švietime tyrimų rezultatai, aptariamos šių tyrimų naujausios tendencijos ir perspektyvos pasaulyje bei Lietuvoje.

Pirmoje dalyje aptariami analizès tikslai, objektas bei taikyti tyrimo metodai. Antroje dalyje pateikiama IKT diegimo švietime ir šios srities tyrimų retrospektyva. Po to aptariami penki iki šiol pasaulyje plačiausiai nagrinèti informacijos technologijos integravimo į ugdymą aspektai: 1) IKT itaka moksleiviu žinioms ir nuostatoms; 2) IKT itaka mokytojui; 3) mokytojo savybiu ir mokymo metodu itaka IKT veiksmingumui; 4) infrastruktūros savybiu ir organizaciniu veiksniu poveikis; 5) programinès irangos savybių veiksmingumas.

Kitoje straipsnio dalyje analizuojamos naujausios pasauliniu IKT diegimo švietime tyrimų tendencijos ir perspektyvos. Pastebima, jog formuojantis holistiniam požiūriui i mokymasi, iš esmès keičiasi IKT vieta ugdymo procese ir IKT tyrimų sritys ir taikomi tyrimų metodai. Po to straipsnyje aptariamos pagrindinès šiuo metu Lietuvai aktualių IKT diegimo švietime tyrimu kryptys: ivairūs informatikos dalyko tyrimai; laipsniškas perẻjimas nuo mokymosi apie IKT per informatikos pamokas prie platesnio IKT integravimo; informacinių igūdžių ugdymas; modeliavimo priemoniu taikymas; mokymosi aplinkų veiksmingumas ir kitos IKT taikymo sritys.

Straipsnio pabaigoje pagrindžiama nacionalinių eksperimentų bei IKT tyrimų svarba, pateikiamas apibendrinimas ir išvados. 